\title{
15. GEOCHEMISTRY AND PETROGRAPHY OF ORGANIC MATTER IN CRETACEOUS SEDIMENTS FROM THE SOUTHEASTERN GULF OF MEXICO, DEEP SEA DRILLING PROJECT HOLE 535-PRELIMINARY RESULTS ${ }^{1}$
}

\author{
Jürgen Rullkötter, Prasanta K. Mukhopadhyay, Birgitta Hartung, and Dietrich H. Welte, \\ Institut für Erdöl und Organische Geochemie (ICH-5), Kernforschungsanlage Jülich GmbH, D-5170 Jülich 1, \\ Federal Republic of Germany
}

\begin{abstract}
Organic geochemical and organic petrographic methods were used to study three Lower to middle Cretaceous sediment samples from Hole 535 in the southeastern Gulf of Mexico for organic matter contents and origin and level of maturation. All three samples contain mixed kerogen Type II/III organic matter with a maturity corresponding to about $0.4 \%$ vitrinite reflectance. The marine component increases with stratigraphic age, and microbial reworking of the organic matter is significant in each age. The lower two samples of Hauterivian to Valanginian age appear to be impregnated (or contaminated) with soluble polar organic compounds, but there is only a weak indication for the presence of more mature, nonindigenous hydrocarbons.
\end{abstract}

\section{INTRODUCTION}

DSDP Leg 77 was planned to investigate in particular the Mesozoic history of the southeastern Gulf of Mexico and to obtain a better understanding of its evolution. Two deep holes were drilled on the continental rise in the western approaches to the Straits of Florida. They penetrated thick sedimentary sequences of Cretaceous to Quarternary age.

DSDP Site 535 (water depth $3455.5 \mathrm{~m}$ ) is located near the axis of a submarine erosional channel that cuts several hundred meters deep into Lower Cretaceous rocks. The sedimentary sequence is divided into five lithologic units. Holocene to upper Pliocene sediments (Unit I, $154 \mathrm{~m}$ ) are unconformably underlain by a sequence of deep-water carbonates of late Berriasian to middle $\mathrm{Ce}$ nomanian age (Units II-V, $560 \mathrm{~m}$ ). Rhythmic alternations of light-colored, bioturbated and dark, partly laminated limestones indicate fluctuating anoxic and oxic bottom conditions. Organic matter-rich marls and marly limestones were encountered in the Berriasian to lowest Albian section. Shipboard inspection of tar-filled fractures in the Valanginian to Hauterivian interval indicated an upward migration of hydrocarbons from deeper, more mature source rocks (site chapter, Site 535, this volume).

This preliminary contribution is based on the organic geochemical and organic petrographic investigation of three sediment samples from Hole 535. The geochemical results concern the amount, type, and diagenesis of the organic matter and the paleoenvironment during deposition, as well as the origin of the organic matter.

\section{EXPERIMENTAL PROCEDURES}

For a detailed description of the experimental procedures for organic carbon determination, Rock-Eval pyrolysis, solvent extraction,

\footnotetext{
${ }^{1}$ Buffler, R. T., Schlager, W., et al., Init. Repts. DSDP, 77: Washington (U.S. Govt. Printing Office).
}

liquid chromatography, and computerized gas chromatography/mass spectrometry, we refer to an earlier report (Rullkötter et al., 1981). For details of the microscopic kerogen investigation see Mukhopadhyay et al. (1983).

\section{RESULTS AND DISCUSSION}

\section{Organic Carbon}

Table 1 shows the total organic carbon contents of three sediment samples from the Valanginian to Cenomanian(?) section of Hole 535. All three samples contain more than $0.3 \%$ organic carbon, often considered as a minimum $\mathrm{C}_{\text {org }}$ level for calcareous hydrocarbon source rocks (e.g., Tissot and Welte, 1978).

\section{Type of Organic Matter}

Rock-Eval pyrolysis for all three samples reveals moderate hydrogen index values (200-350 mg hydrocarbons/g

Table 1. Organic carbon contents, total extract yields, and Rock-Eval pyrolysis data for sediment samples from Hole 535 .

\begin{tabular}{|c|c|c|c|}
\hline \multirow[b]{2}{*}{ Characteristic } & \multicolumn{3}{|c|}{$\begin{array}{c}\text { Core-Section } \\
\text { (interval in cm) }\end{array}$} \\
\hline & $\begin{array}{l}535-41-6 \\
120-150\end{array}$ & $\begin{array}{l}535-60-5 \\
120-150\end{array}$ & $\begin{array}{l}535-66-5 \\
120-150\end{array}$ \\
\hline Sub-bottom depth (m) & 381.9 & 550.4 & 604.4 \\
\hline Stratigraphy & Cenomanian(?) & $\begin{array}{l}\text { Hauterivian- } \\
\text { Valanginian }\end{array}$ & Valanginian \\
\hline Lithology & $\begin{array}{l}\text { Light gray } \\
\text { limestone }\end{array}$ & $\begin{array}{l}\text { Olive gray marly } \\
\text { limestone }\end{array}$ & $\begin{array}{l}\text { Olive black marly } \\
\text { limestone }\end{array}$ \\
\hline Organic carbon $(\%)$ & 0.98 & 0.46 & 1.24 \\
\hline \multicolumn{4}{|l|}{ Extract } \\
\hline (mg) & 15.2 & 11.1 & 60.9 \\
\hline (mg/g C & 15.5 & 28.3 & 54.6 \\
\hline \multicolumn{4}{|l|}{ Liquid chromatography } \\
\hline Nonaromatic HC (\%) & 7.2 & 4.6 & 2.1 \\
\hline Aromatic $\mathrm{HC}(\%)$ & 8.7 & 7.3 & 4.2 \\
\hline Heterocompounds (\%) & 84.1 & 88.1 & 93.7 \\
\hline \multicolumn{4}{|l|}{ Rock-Eval pyrolysis } \\
\hline $\begin{array}{l}\text { Hydrogen index } \\
\text { (mg HC/g C } / \text { org) }\end{array}$ & 228 & 277 & 344 \\
\hline $\begin{array}{l}\text { Oxygen index } \\
\left(\mathrm{mg} \mathrm{CO} 2 / \mathrm{g} \mathrm{C}_{\text {org }}\right)\end{array}$ & 116 & 139 & 79 \\
\hline $\mathrm{T}_{\max }\left({ }^{\circ} \mathrm{C}\right)$ & 421 & 420 & 421 \\
\hline
\end{tabular}

Note: $\mathrm{HC}=$ hydrocarbons. 
$\mathrm{C}_{\text {org }}$ ) and low oxygen index values (Table 1, Fig. 1). Figure 1 demonstrates that the organic matter in all three samples represents a mixed Type II and Type III kerogen. The decrease of the hydrogen index with decreasing depth could mean that conditions for the preservation of organic matter deteriorated with time, which often leads to a higher proportion of the less-degradable terrigenous organic matter in the kerogen (cf. Table 2). This corresponds to the generally lighter color of the limestone in the upper part of the Cretaceous section at Site 535 .

Table 2 gives the results of the organic facies analysis as observed microscopically from the maceral composition. All the samples analyzed contain more than $50 \%$ amorphous organic matter. The Cenomanian(?) sample (535-41-6, 120-150 cm) contains even 75\% amorphous organic matter as bituminite II (i.e., the degradation product of phytoplankton and zooplankton and/or bacterially altered higher-plant liptinites) and bituminite III (i.e., degraded humic ligno-cellulose and higher-plant liptinites) (Gormly and Mukhopadhyay, 1983; Rullkötter et al., in press). Apart from this completely degraded

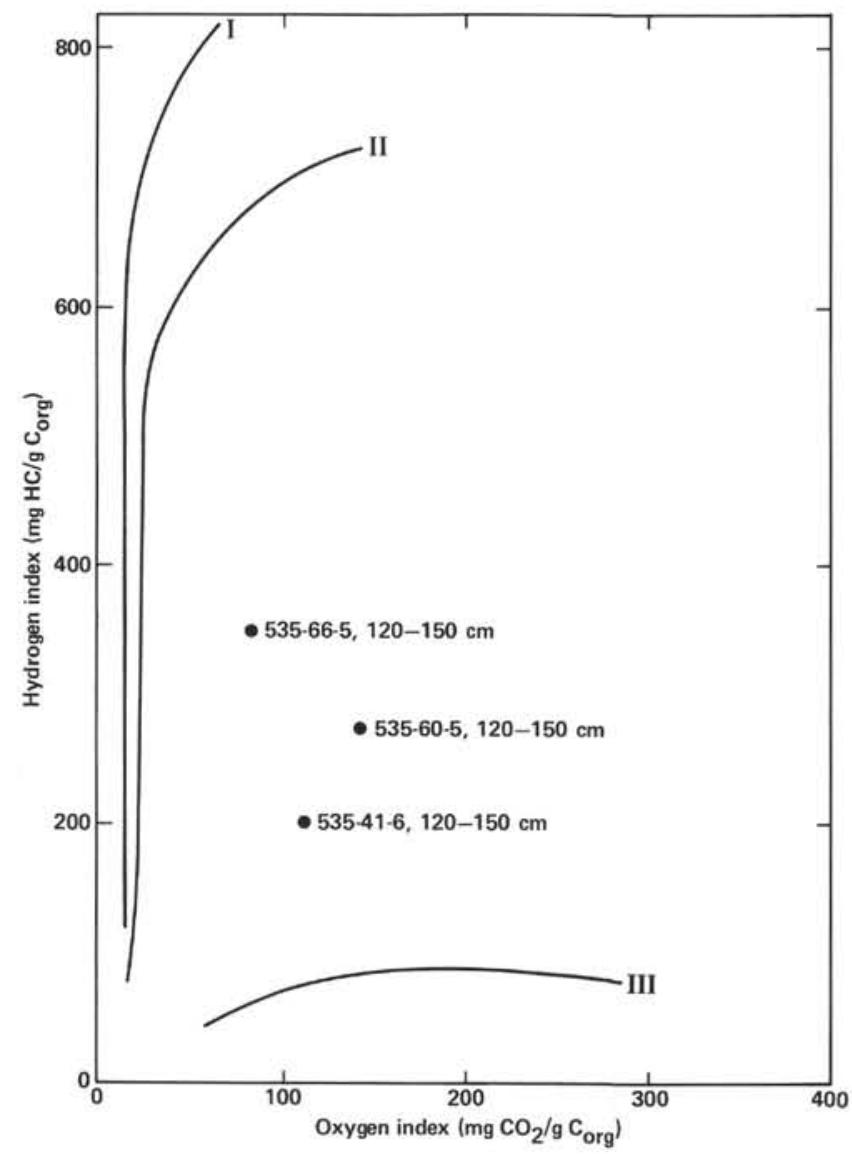

Figure 1. Results of Rock-Eval pyrolysis displayed as hydrogen index versus oxygen index diagram (Espitalié et al., 1977) for sediment samples from DSDP Hole 535. I, II, III: simplified kerogen classification defining Type I (mainly algal material), Type II (mainly phytoplankton and zooplankton), and Type III (mainly vitrinite and biodegraded humic matter of higher plant origin). The lines represent trend lines for the different types of kerogen with increasing maturation.
Table 2. Organic petrography data for sediment samples from Hole 535.

\begin{tabular}{|c|c|c|c|}
\hline \multirow[b]{2}{*}{ Characteristic } & \multicolumn{3}{|c|}{$\begin{array}{l}\text { Core-Section } \\
\text { (interval in cm) }\end{array}$} \\
\hline & $\begin{array}{l}535-41-6 \\
120-150\end{array}$ & $\begin{array}{l}535-60-5 \\
120-150\end{array}$ & $\begin{array}{l}535-66-5 \\
120-150\end{array}$ \\
\hline \multicolumn{4}{|l|}{$\begin{array}{l}\text { Maceral analysis } \\
\text { (\% by volume) }\end{array}$} \\
\hline Vitrinite & 5 & 5 & 4 \\
\hline Inertinite & 5 & 5 & 2 \\
\hline Bituminite III & 50 & 32 & 30 \\
\hline $\begin{array}{l}\text { Particulate terrestrial } \\
\text { liptinites }\end{array}$ & 10 & 18 & 6 \\
\hline Phytoclasts/Zooclasts b & 3 & 14 & 24 \\
\hline Alginite & 2 & 2 & 4 \\
\hline $\begin{array}{l}\text { Bituminite II + } \\
\quad \text { liptodetrinite }\end{array}$ & 25 & 24 & 30 \\
\hline $\begin{array}{l}\text { Mean vitrinite reflectance } \\
\quad(\mathrm{Rm}[\%] \pm \mathrm{SD})\end{array}$ & $0.46 \pm 0.09$ & $0.37 \pm 0.04$ & $0.43 \pm 0.03$ \\
\hline \multicolumn{4}{|l|}{ Spectral fluorescence ${ }^{c}$} \\
\hline$\lambda_{\max }$ & 542 & $\begin{array}{l}\text { ND } \\
\text { ND }\end{array}$ & 527 \\
\hline$Q$ & 0.71 & ND & 0.58 \\
\hline
\end{tabular}

Note: Sub-bottom depth, stratigraphy, lithology, and percent $\mathrm{C}_{\text {org }}$ are given in Table 1.

a Sporinite, cutinite, resinite, suberinite.

b Fragments or whole particles of phytoplanktons or zooplanktons other than colonial algae.

$c^{c} \lambda_{\max }=$ wavelength of maximum fluorescent intensity; mean of 10 measurements on sporinite. $Q=$ fluorescent intensity at $650 \mathrm{~nm} / \mathrm{flu}-$ roescent intensity at $500 \mathrm{~nm}$; mean of 10 measurements. ND = not determined.

amorphous organic matter, we observed some partially degraded macerals that retain much of their original structure, e.g., sporinites and dinoflagellate clasts, and are called liptodetrinite by Stach et al. (1982).

The Cenomanian(?) sample (535-41-6, 120-150 cm) contains abundant bituminite III with only little micrinite (small inertinite particles). The amount of micrinite is remarkably low when compared with the Cretaceous samples from DSDP Leg 76 (Blake-Bahama Basin), which also contained an abundance of bituminite III (Mukhopadhyay, Rullkötter, Disko, Schaefer, and Welte, unpublished data). This indicates a lower degree of oxidation for the organic matter in the Cenomanian(?) sample from Site 535 (Stach et al., 1982). Less exposure of the terrestrial organic matter to oxic conditions may have been caused by more rapid sedimentation or by the closer proximity of Site 535 to the continental source.

Bituminite II in the Cenomanian(?) sample shows a close morphologic similarity to bituminite III (oval or rounded, sometimes shapeless), but it differs in fluorescent color, which was our means for differentiating the two bituminite types.

The two Valanginian samples differ from each other mainly in their particulate terrestrial or marine liptinite proportions. Sample 535-60-5, 120-150 cm contains more sporinite and cutinite, whereas Sample 535-66-5, 120 $150 \mathrm{~cm}$ contains more dinoflagellate clasts. The amount of bituminite II in the latter sample is slightly higher. In both samples, bituminite II often shows relict spore or dinoflagellate structures, which suggest that this material is a typical microbial degradation product of terrestrial and marine liptinites. The presence of relict structures 
indicates less degradation than in the Cenomanian(?) sample. Bituminite III in both Valanginian samples is grainy and gray and has an appearance similar to the vitrinite particles in the same sample, although bituminite III shows a slightly lower reflectance than the telocollinite.

Besides some primary vitrinite particles the Cenomanian(?) sample contains a high proportion of recycled vitrinite with a $R_{m}$ value of about $0.75 \%\left(R_{m}=\right.$ mean reflectance under oil immersion). The Hauterivian-Valanginian sample (Core 535-60) contains a few recycled vitrinite specimens of about $0.8 \% R_{m}$, but recycled vitrinite is almost absent in the Valanginian sample from Core 535-66.

\section{EXTRACTABLE ORGANIC MATTER}

The amount of organic matter extractable is as expected for an immature sediment for the Cenomanian(?) sample (Table 1), but unusually high in Sample 535-60$5,120-150 \mathrm{~cm}$ (Hauterivian-Valanginian) and especially in the Valanginian sample from Section 535-66-5 (54.6 $\mathrm{mg} / \mathrm{g} \mathrm{C}_{\text {org }}$; cf. Rullkötter et al., 1981). This either points to shipboard contamination with soluble organic matter, e.g., pipe dope (Brassell and Eglinton, 1981), or to an impregnation with migrated hydrocarbons, e.g., related to the tar-filled fractures in the Valanginian to Hauterivian interval at DSDP Site 535.

Capillary column gas chromatograms of the nonaromatic hydrocarbon fractions are shown in Figure 2 for the Cenomanian(?) (Fig. 2a) and the Valanginian samples (Fig. 2b). The Hauterivian-Valanginian sample from Core 535-60 has a nonaromatic hydrocarbon distribution similar to the Valanginian sample, but with a pronounced broad hump of unresolved compounds (contamination?).

The Cenomanian(?) sample contains a dominance of long-chain $n$-alkanes derived from higher-plant waxes (Eglinton and Hamilton, 1963) with a maximum at $n$ - $\mathrm{C}_{25}$; the maximum at this relatively low carbon number may be an effect of microbial reworking of the wax alkanes (Simoneit et al., 1979 and references therein). A slight dominance of phytane over pristane (pri/phy = 0.84 ) at the low maturity level indicated by the dominance of odd-numbered over even-numbered $n$-alkanes points to environmental conditions during deposition, predominantly favorable for organic matter preservation (Didyk et al., 1978). The abundance of pristane, phytane, and the cyclic compounds is consistent with a moderate content of marine organic matter in the Cenomanian(?) sample. The cyclic compounds predominantly consist of $17 \beta(\mathrm{H})$-hopanes and hopenes, which are probably of bacterial origin (Ourisson et al., 1979), and of $5(\mathrm{H})$-steranes, $5(\mathrm{H})$-steranes, and rearranged sterenes, which based on their relative abundance support the idea of a significant marine organic matter contribution to the sediment (cf. Rullkötter et al., 1981). The amount of regular sterenes present, in view of the low maturation level, is surprisingly low. The occurrence of rearranged sterenes indicates a significant clay component in the mineral matrix (Rubinstein et al., 1975). Although limestone is the general lithology of Sample
$535-41-6,120-150 \mathrm{~cm}$, there is a significant clay component based on smear-slide observation (site chapter, Site 535 , this volume).

The $n$-alkanes within the Valanginian sample show a smooth distribution without carbon number preference and with a maximum at $n-\mathrm{C}_{17}$. Such a distribution is atypical of immature deep-sea sediments, especially if they are rich in organic matter. The $n$-alkane distribution resembles that of a mature sediment or a crude oil. In contrast to this is the high abundance of pristane, phytane $\left(\mathrm{pri} / \mathrm{phy}=1.05 ; \mathrm{pri} / n-\mathrm{C}_{17}=3.5\right.$, based on peak areas), and the cyclic components eluted after $n$ $\mathrm{C}_{25}$, which are typical of immature organic matter in sediments. If Sample 535-66-5, 120-150 cm was impregnated (or contaminated) by an oil-like substance predominantly represented by the "mature" $n$-alkanes, this would not account for the very high total extract of 54.6 $\mathrm{mg} / \mathrm{g} \mathrm{C}_{\text {org. }}$. Consequently, either the impregnating/contaminating material mainly consists of polar material (the heterocompound fraction comprises $93.7 \%$ of total extract by liquid chromatography), or there are two sources of impregnation/contamination and the minor nonpolar one is responsible for the $n$-alkane distribution. Compared to the Cenomanian(?) sample, steroid hydrocarbons in the Valanginian sample, are (based on a cursory examination of gas chromatography/mass spectrometry data) more abundant, which is consistent with the higher proportion of marine liptinite observed microscopically in the Cenomanian(?) sediment. The cyclic hydrocarbons bear the characteristics of low maturation, i.e., $17 \beta(\mathrm{H})$-hopanes and $5 \beta$-steranes, $5 \alpha(\mathrm{H})$ steranes, $14 \alpha(\mathrm{H})$-steranes, and $17 \alpha(\mathrm{H})$-steranes with the 20R-configuration dominant (cf. Mackenzie and Maxwell, 1981; Rullkötter et al., 1981). The discrepancy between the $n$-alkane distribution without a distinct carbon number preference and the presence of biological marker compounds in their immature configuration clearly indicates the presence of nonindigenous hydrocarbons.

\section{Diagenesis/Maturation}

Three parameters were studied to assess the degree of kerogen maturation. The mean vitrinite reflectance values $\left(R_{m}\right)$ measured on primary vitrinite particles vary between 0.37 and $0.46 \%$. There is no general trend of increasing vitrinite reflectance with depth; moreover, the deepest sample shows a slightly lower reflectance than the shallowest (Table 2) for which, however, the highest standard deviation was obtained, indicating that some recycled vitrinites may have been included. The spectral fluorescence parameters $\lambda_{\max }$ (wavelength of maximum fluorescence intensity) and $Q$ (red/green quotient) (Stach et al., 1982; Teichmüller and Ottenjann, 1977) show a similar effect of maturation opposite to the present depth sequence. $\lambda_{\max }$ and $Q$ values of $542 / 0.71$ and $527 / 0.58$ correspond to vitrinite reflectance values of 0.4 and $0.3 \% \mathrm{R}_{\mathrm{m}}$, respectively (Teichmüller and Ottenjann, 1977). The temperatures of maximum pyrolysis yield $\left(\mathrm{T}_{\max }{ }^{\circ} \mathrm{C}\right.$; Espitalié et al., 1977) range from 420 to $421^{\circ} \mathrm{C}$. This corresponds to about $0.4 \% \mathrm{R}_{\mathrm{m}}$ and does not suggest a significant increase of maturity with depth. 

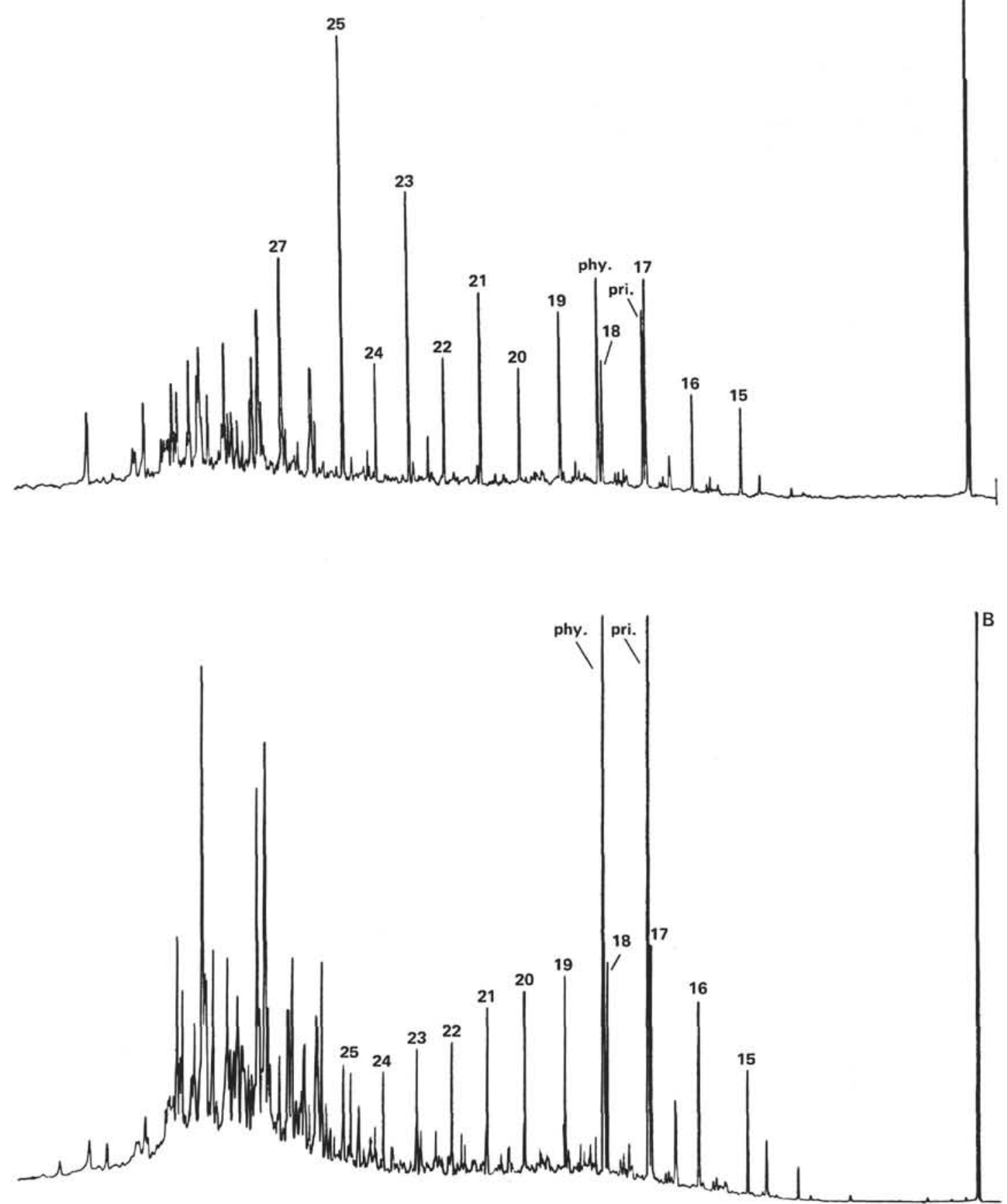

Figure 2. Capillary column gas chromatograms of the nonaromatic hydrocarbon fractions of (A) Sample 535-41-6, 120$150 \mathrm{~cm}$ (381.9 m sub-bottom depth, Cenomanian?) and (B) Sample 535-66-5, 120-150 cm (604.4 m sub-bottom depth, Valanginian). Numbers indicate $n$-alkanes; pri. = pristane; phy. = phytane.

The maturation level of the organic matter of all three samples (mixed Type II/III kerogen, observed from the mean vitrinite reflectance data, spectral fluorescence values, and temperatures of maximum pyrolysis yield) is well before the onset of thermal hydrocarbon generation. Hence, the maturation data suggest that the tar encountered in the Hauterivian to Valanginian interval, which represents a mature hydrocarbon mixture (Pala- cas et al., this volume), did not originate in these strata but in more mature source rocks.

\section{CONCLUSIONS}

Kerogen microscopy and Rock-Eval pyrolysis revealed a mixed Type II/III kerogen in the three Valanginian to Cenomanian(?) sediment samples from DSDP Hole 535 in the southeastern Gulf of Mexico. The amount of ma- 
rine organic matter in the calcareous sediments, which contain between about 0.5 and $1.2 \%$ total organic carbon, increases with stratigraphic age. More than $50 \%$ of the organic matter has been microbially degraded in each case, whereas the presence of reworked vitrinite of higher maturity is significant only in the shallowest sample investigated.

The chemical composition of the extractable nonaromatic hydrocarbons, as well as the preservation of the particulate organic matter, indicate that more or less anoxic conditions prevailed during deposition. The organic matter appears to be immature in all samples investigated; the maturation level corresponds to about $0.4 \%$ vitrinite reflectance. Impregnation (or contamination) by polar organic compounds is evident in the lower two sediment samples (increasing with depth) from the total extract yields, but there is only a slight indication for the presence of mature, nonindigenous, nonpolar hydrocarbons in the Valanginian sample from Core 535-66.

\section{ACKNOWLEDGMENTS}

We thank Drs. J. Gormly, M. Radke, and R. G. Schaefer for RockEval pyrolysis, extraction/liquid chromatography, and gas chromatography, respectively, and W. Benders, U. Disko, and Miss K. Sellinghoff for technical assistance. Financial support by the Deutsche Forschungsgemeinschaft (DFG, Bonn), Grant No. We-346/25, is gratefully acknowledged.

\section{REFERENCES}

Brassell, S. C., and Eglinton, G., 1981. Organic geochemical studies of two samples from Holes 447A and 448 from Deep Sea Drilling Project Leg 59. In Kroenke, L., Scott, R., et al., Init. Repts. DSDP, 59: Washington (U.S. Govt. Printing Office), 647-648.

Didyk, B. M., Simoneit, B. R. T., Brassell, S. C., and Eglinton, G., 1978. Organic geochemical indications of palaeoenvironmental conditions of sedimentation. Nature, 272:216-222.

Eglinton, G., and Hamilton, R. J., 1963. The distribution of alkanes. In Swain, T. (Ed.), Chemical Plant Taxonomy: London (Academic Press), pp. 187-217.

Espitalié, J., Laporte, J. L., Madec, M., Marquis, F., Leplat, P., Poullet, S., and Boutefeu, R., 1977. Méthode rapide de caractérization des roches-mères, de leur potentiel pétroliér et de leur degré d'évolution. Rev. Inst. Fr. Petrol., 32:23-42.

Gormly, J., and Mukhopadhyay, P. K., 1983. Hydrocarbon potential of kerogen types by pyrolysis-gas chromatography. In Bjorøy, M., et al. (Eds.), Advances in Organic Geochemistry-1981: Chichester (Wiley), pp. 597-606.

Mackenzie, A. S., and Maxwell, J. R., 1981. Assessment of thermal maturation in sedimentary rocks by molecular measurements. In Brook, J. (Ed.), Organic Maturation Studies and Fossil Fuel Exploration: New York (Academic Press), pp. 239-254.

Mukhopadhyay, P. K., Rullkötter, J., and Welte, D. H., 1983. Facies and diagenesis of organic matter in sediments from the Brazil Basin and the Rio Grande Rise, Deep Sea Drilling Project Leg 72. In Barker, P. F., Carlson, R. L., Johnson, D. A., et al., Init. Repts. DSDP, 72: Washington (U.S. Govt. Printing Office), 821-828.

Ourisson, G., Albrecht, P., and Rohmer, M. 1979. The hopanoids paleochemistry and biochemistry of a group of natural products. Pure Appl. Chem., 51:709-729.

Rubinstein, I., Sieskind, O., and Albrecht, P., 1975. Rearranged sterenes in a shale: occurrence and simulated formation. J. Chem. Soc. Perkin Trans. I, 1833-1836.

Rullkötter, J., Mukhopadhyay, P. K., and Welte, D. H., in press. Geochemistry and petrography of organic matter in sediments from Deep Sea Drilling Project Holes 530A, Angola Basin, and 532, Walvis Ridge. In Hay, W. W., Sibuet, J.-C., et al., Init. Repts. DSDP, 75: Washington (U.S. Govt. Printing Office).

Rullkötter, J., von der Dick, H., and Welte, D. H., 1981. Organic petrography and extractable hydrocarbons of sediments from the eastern North Pacific Ocean, Deep Sea Drilling Project Leg 63. In Yeats, R. S., Haq, B. U., et al., Init. Repts. DSDP, 63: Washington (U.S. Govt. Printing Office), 819-836.

Simoneit, B. R. T., Mazurek, M. A., Brenner, S., Crisp, P. T., and Kaplan, I. R., 1979. Organic geochemistry of recent sediments from Guaymas Basin, Gulf of California. Deep-Sea Res., 26A:879-891.

Stach, E., Mackowsky, M. T., Teichmüller, M., Taylor, G. H., Chandra, D., and Teichmüller, R., 1982. Coal Petrology (2nd ed.): Berlin, Stuttgart (Gebrüder Bornträger).

Teichmüller, M., and Ottenjann, K., 1977. Art und Diagenese von Liptiniten und lipoiden Stoffen in einem Erdölmuttergestein aufgrund fluoreszenzmikroskopischer Untersuchungen. Erdol Kohle Petrochem., 30:387-398.

Tissot, B. P., and Welte, D. H., 1978. Petroleum Formation and Occurrence. A New Approach to Oil and Gas Exploration: Berlin, Heidelberg, New York (Springer-Verlag).

Date of Initial Receipt: February 9, 1983

Date of Acceptance: June 22, 1983 